\author{
Natalia DŁugosz \\ Uniwersytet im. Adama Mickiewicza w Poznaniu \\ Instytut Filologii Słowiańskiej
}

\title{
Polskie i bułgarskie rzeczowniki złożone z członami homo- / хомо- $i$ gej- / zeŭ- jako przejaw internacjonalizacji słowotwórstwa w języku mediów
}

Słowa klucze: słowotwórstwo polsko-bułgarskie, composita rzeczownikowe, język mediów

Obserwacje współczesnych systemów słowotwórczych wybranych języków słowiańskich, zwłaszcza w kontekście ostatnich dziesięcioleci, ukazują, że nie tylko znacznie w nich wzrosła liczba wyrazów złożonych, ale powstały też nowe, produktywne modele. Uwagę zwracają zwłaszcza następujące typy złożeń:

- nowe wyrazy złożone o podstawie zdezintegrowanej, np.: pol. biogazownia, ekopuzzle, euromyślenie, homotata, katoidiota, e-podryw, erofota, narkoprzemyt, pornoklientela; bułg. биосалам, хомонаклонност, екобъдеще, европоведение, еростимулант, е-общество i in.

Koniecznym do utworzenia formacji środkiem słowotwórczym jest ucięcie (dezintegracja) pierwszego z członów. Przy czym pierwszy człon złożenia występuje w funkcji określającej w stosunku do członu drugiego. Zatem w omawianych compositach rzeczownikowych komponenty wyrazu złożonego łączą się bezpośrednio (bezafiksalnie).

- nowe wyrazy złożone z dwu podstaw rzeczownikowych (licznie obecne zwłaszcza w języku bułgarskim), z których każda może funkcjono- 
wać jako samodzielny leksem, np.: pol. euroczek, sekswitryna, gejturystyka; bułg. еврочент, гейшествие, чалгаманталитет, допингскандал, екшънгерой.

Podobnie jak w przypadku pierwszej grupy wyrazów, człony złożenia połączone są bezspójkowo. Analogiczny jest też typ relacji między nimi.

Struktury słowotwórcze stanowiące przedmiot analizy postrzegane są jako jeden z przejawów internacjonalizacji przy okazji omawiania nowych tendencji we współczesnych systemach słowotwórczych języków słowiańskich ${ }^{1}$. W opracowaniach dotyczących lawinowego wzrostu liczby compositów omawia się zwłaszcza budowę słowotwórczą derywatów, sposób ich funkcjonowania w tekście oraz dokonuje się charakterystyki nowego modelu. Niekiedy poruszany jest także socjolingwistyczny aspekt zagadnienia. Warto w tym miejscu zwrócić uwage na trudności związane z klasyfikacją nowych struktur złożonych oraz z nazwaniem techniki słowotwórczej, w oparciu o którą powstają. W polonistycznej literaturze przedmiotu oglądu stanowisk w zakresie problemu dokonuje m.in. Iwona Burkacka (2010).

W niniejszym artykule skupiam uwagę na najnowszych wyrazach złożonych z pierwszym członem obcym hoто - / хомо - i gej- / геŭ- w języku polskim i bułgarskim. Zważywszy na propagowaną w Europie politykę tolerancji wobec osób innej orientacji seksualnej, wzrost liczby i częstości omawianych złożeń wydaje się uzasadniony. Zaznaczam jednak, że opisane prawidłowości dotyczą przede wszystkim języka mediów. Zgromadzony bowiem materiał językowy czerpię w szczególności z nagłówków oraz tekstów artykułów prasy bułgarskiej i polskiej ${ }^{2}$, dostępnych w wersji elektronicznej, oraz z nagłówków i tekstów artykułów zamieszczonych na portalach internetowych ${ }^{3}$. Zatem opierając się na poczynionych obserwacjach, można wnio-

1 Zagadnienie to poruszają m.in.: 1) w stosunku do języka polskiego: Jadacka 2001, Ochmann 2004, Ohnheiser (red.) 2003, Waszakowa 2005; 2) w stosunku do języka bułgarskiego: Аврамова 2003, Благоева 2007, Бонджолова 2009, Зидарова 2009.

2 Zgromadzony materiał pochodzi przede wszystkim $\mathrm{z}$ następujących e-gazet i e-czasopism: pol. „Dziennik”: www.dziennik.pl, „Gazeta Wyborcza”: www.wyborcza. pl, „Rzeczpospolita”: www.rzeczpospolita.pl, „Trybuna”: www.trybuna.com.pl, „Super Expres”: www.se.com.pl, „Fakt”: www.efakt.pl; bułg. „Дневник”: www.dnevnik. bg, „Капитал”: www.capital.bg, „Монитор”: www.monitor.bg, „Труд”: www.trud.bg, „Сега”: www.segabg.com, „24 часа”: www.24chasa.bg.

${ }^{3}$ Polskie strony WWW: www.onet.pl, www.wp.pl, www.interia.pl, www.forum.polityka.org.pl, www.polskaliberalna.net, www.fidelitas.pl; bułgarskie strony WWW: www. dir.bg, www.news.ibox.bg, www.novinar.bg, www.dariknews.bg, www.bgspider.com. 
skować jedynie o pewnych elementach komunikacyjnej strategii, obieranej przez środki masowego przekazu ${ }^{4}$.

Opis budowy słowotwórczej, uwzględniający wzajemny stosunek składników złożenia, nie nastręcza zbytnich trudności. Bez wątpienia kompozycja (głównie za sprawą języka angielskiego) jest aktualnie niezwykle aktywnym modelem słowotwórczym zarówno w polszczyźnie, jak i bułgarszczyźnie. Najogólniej rzecz ujmując, derywaty, na których skupiam uwagę, przynależą do grupy złożeń bezspójkowych z pierwszym członem obcym. O ile w przypadku najnowszych compositów z członem hoто - / хомо- mamy do czynienia z ucięciem (dezintegracją) jednej z podstaw złożenia, o tyle człon gej- / геŭ- jest samodzielnie funkcjonującym leksemem. Są to struktury niewspółrzędne, w których człon nadrzędny (określany za pomocą członu obcego) zajmuje prawą stronę binarnej konstrukcji ${ }^{5}$.

Zgromadzony i poddany analizie materiał obejmuje:

1) dla języka polskiego: 87 derywatów złożonych z członem homo(85 rzeczowników, 1 przymiotnik, 1 przysłówek) oraz zaledwie 12 złożeń z pierwszym członem gej- (wyłącznie rzeczowniki);

2) dla języka bułgarskiego: 61 derywatów złożonych z członem хомо(60 rzeczowników, 3 przymiotniki) oraz 158 złożeń z pierwszym członem гей- (wyłącznie rzeczowniki).

Na podstawie powyższych danych łatwo stwierdzić, że człony ho mo - / хомо- i gej- / гей- występuja przede wszystkim w derywatach rzeczownikowych. Odnotowano zaledwie po kilka przykładów złożeń dla każdego z języków, które rzeczownikami nie są, a mianowicie: pol. homoerotyczny, hoтоinaczej; bułg. хомоеротичен, хомоеротомански, хомофобски.

W pierwszej grupie compositów zarówno polskich, jak i bułgarskich komponent homo- / хомо - postrzegany jest jako skrócona podstawa zdezintegrowana pochodząca od przymiotnika 'homoseksualny' (np. pol. homomiłość, homopara, homorodzice; bułg. хомомъж, хомонаклонност, хомоориентация) lub od rzeczownika 'homoseksualista' (np. pol. homo-

${ }^{4}$ Na obecność dwu przeciwstawnych tendencji w słowotwórstwie współczesnego języka polskiego, tj. z jednej strony tendencji do globalizacji w odniesieniu do komunikatów pisanych, przekazywanych za pośrednictwem mediów, oraz z drugiej strony tendencji do regionalizacji w odniesieniu do komunikatów mówionych, zwłaszcza w sytuacjach komunikacji niesformalizowanej, zwraca uwagę M. Szczyszek (2010).

5 O binarnym charakterze złożeń zob. Nagórko 1997. 
impreza 'impreza dla lub z udziałem homoseksualistów', homoigrzyska 'igrzyska dla homoseksualistów', homoparada 'parada homoseksualistów'; bułg. хомосреща 'среща на хомосексуалисти', хомодемонстрация 'демонстрация на хомосексуалисти'). W większości przypadków formacje te na poziomie syntaktycznym mają swoje odpowiedniki w postaci frazy nominalnej z zależnym przymiotnikiem ${ }^{6}$, np. pol. homobohater - 'bohater homoseksualny', homofantazje - 'fantazje homoseksualne', homomatżeństwo - 'małżeństwo homoseksualne'; bułg. хомопартньор - 'хомосексуален партньор', хомостраст - 'хомосексуална страст', хомовръзка 'хомосексуална връзка'. Z obserwacji kontekstowej, uwzględniającej użycie wyrazu w tekście, wynika, że w języku mediów bułgarskich tego typu konstrukcje występują głównie w tytułach artykułów, podczas gdy w samym tekście artykułu najczęściej zastępują je frazy. W odniesieniu do języka polskiego derywaty występują w podobnym natężeniu zarówno w tytule, jak i w tekście właściwym artykułu. Wydaje się to o tyle zaskakujące, że nie koresponduje $\mathrm{z}$ właściwościami wewnątrzsystemowymi omawianych języków, a mianowicie, mając na względzie analityczny charakter języka bułgarskiego i syntetyczny polszczyzny, można by oczekiwać raczej sytuacji odwrotnej.

Z kolei z pobieżnej kwerendy internetowej, dokonanej przy wykorzystaniu jednej z najpopularniejszych wyszukiwarek, tj. wyszukiwarki Google.pl dla języka polskiego i Google.bg dla języka bułgarskiego, wynika, że liczba użyć formacji złożonych w porównaniu $\mathrm{z}$ odpowiadającymi im frazami nominalnymi jest najczęściej co najmniej kilkakrotnie mniejsza zarówno w języku polskim, jak i bułgarskim. Zabiegowi badania internetowego poddałam przytoczone wcześniej przykłady. Badanie miało prosty przebieg: wybrane leksemy wpisałam do wyszukiwarki, przy czym w celu uzyskania jak najdokładniejszych wyników użyłam opcji wyszukiwania zaawansowanego. Funkcja ta pozwala m.in. na wykluczenie z liczby otrzymanych wyników

${ }^{6}$ Nie wszystkie wyrazy uwzględnione w indeksie mają odpowiednik w postaci frazy nominalnej. Niektóre z wymienionych złożeń to doraźnie utworzone, skondensowane struktury o charakterze analogicznym. 
częstych powtórzeń tych samych kontekstów użycia leksemu ${ }^{7}$ Badanie przyniosło następujące rezultaty ${ }^{8}$ :

a) materiał polski: homobohater 155 / bohater homoseksualny 575, homofantazje 82 / fantazje homoseksualne 1670, homomatzeństwo 358 / matżeństwo homoseksualne 31 800, homomiłość 1480 / miłość homoseksualna 25 800, homopara 83 / para homoseksualna 29 400, homorodzice 2750 / rodzice homoseksualni 7360 ;

b) materiał bułgarski: хомородители 5 / хомосексуални родители 1390, хомопарньор 10 / хомосексуален партньор 1060, хомостраст 4 / хомосексуална страст 328, хомовръзка 432 / хомосексуална връзка 12300 , хомомъж 1 / хомосексуален мъж 5 310, хомонаклонност 1 / хомосексуална наклонност 158, хомоориентация 72 / хомоселсуална ориентащия 28 600, хомосрещз 1 / хомосексуална среща 4, хомодемонстрачия 1 / хомосексуална демонстариия 6, хомопарад 284 / парад на хомосексуалистите 16200.

Przedstawione dane dokumentują częstość występowania derywatów oraz ich ekwiwalentów w postaci fraz nominalnych. Okazuje się, że genetycznie obce struktury compositów występują w tekstach zarówno polskich, jak i bułgarskich wielokrotnie rzadziej aniżeli struktury oparte na rodzimych środkach językowych. W materiale polskim wyjątek od tej reguły stanowią jedynie pary: homoigrzyska 1130 / igrzyska homoseksualne 3, homoigrzyska 1130 / igrzyska homoseksualistów 15, homoparada 7510 / parada homoseksualistów 5450, homoeuropa 247 / homoseksualna Europa 224.

W drugiej grupie compositów z członem gej- / zeŭ- sytuacja wygląda inaczej. W bułgarskich złożeniach mamy do czynienia z komponentem, który jest jednoznacznie interpretowany jako podstawa rzeczownikowa (Аврамова 2003: 172): „гей - лице с хомосексуална ориентация, наклонности; хомосексуалист. Анг. Gay" (РНДБЕ 2006: 73). W języku polskim komponent można postrzegać zarówno jako pochodzący od rzeczownika gej, jak i od przymiotnika gejowski.

7 Otrzymane w drodze kwerendy internetowej dane traktuję jedynie orientacyjnie. Jak bowiem wiadomo, określone narzędzia internetowe wskazują ograniczoną liczbę kontekstów użycia leksemu lub frazy, w związku z czym wynik badania zależy w dużej mierze zarówno od potencjału wykorzystanej wyszukiwarki, jak i od rodzaju łącza.

8 Wskazuję liczbę kontekstów dla danego zapytania. 
W języku bułgarskim composita z pierwszym członem ze ŭ- tworzą w porównaniu z językiem polskim bardzo liczną serię i trudno dokonać szczegółowych obliczeń, ponieważ omawianego typu formacje mają charakter otwarty, tj. łączliwość członów zwłaszcza z podstawami rzeczownikowymi nie napotyka na ograniczenia. W związku z powyższym seria może się rozrastać poprzez innowacyjną działalność każdego z użytkowników języka w sposób niekontrolowany. Polszczyzna natomiast od zapożyczonego rzeczownika gej utworzyła za pomocą rodzimych środków słowotwórczych przymiotnik gejowski $i^{9}$ W zgromadzonym materiale polskim wystąpiło niewiele, bo zaledwie kilkanaście przykładów złożeń z pierwszym członem gej-, który może być postrzegany zarówno jako pochodzący od rzeczownika gej, jak i jako skrócona podstawa przymiotnikowa. Są to następujące przykłady: gejbar, gejturystyka, gejikona, gejdyskoteka, gejliteratura, gejpara, gejstyl, gejparada, gejspołeczność, gejportal, gejklub, gejpartner. Zdecydowanie częściej w polskich tekstach prasowych stosowana jest fraza nominalna z przymiotnikiem gejowski, np. portal gejowski, społeczność gejowska itp.

Dokonana w odniesieniu do materiału polskiego kwerenda internetowa wykazała, że również w tym wypadku częstość występowania compositów w tekstach jest zdecydowanie niższa aniżeli częstość odpowiadających im fraz. Oto wyniki badania: gejikona 35 / ikona gejów 1750, gejturystyka 613 / turystyka gejowska 5450, gejklub 1240 / klub gejowski 8770, gejliteratura 85 / literatura gejowska 52 900, gejstyl 95 / styl gejowski 419, gejspołeczność 3 / społeczność gejowska 5740, gejportal 3430 / portal gejowski 54100. Wyłącznie w przypadku dwu derywatów kwerenda nie wykazała tej prawidłowości. Są to: gejbar 3400 / bar gejowski 2250, gejpara 3470 / para gejowska 1970.

Badanie przeprowadzone na analogicznych przykładach bułgarskich udokumentowało, że w języku mediów bułgarskich nowe złożenia z komponentem гей- występują zdecydowanie częściej aniżeli ich ekwiwalenty o strukturze $\mathrm{S}+\mathrm{PRP} \cap \mathrm{S}^{10}$. Poniżej prezentuję wyniki kwerendy: гейбap 31160 / бар за гейове 646, гейикона 25309 / икона на гейове 0, гейтуризъм

${ }^{9}$ gejowski - charakterystyczny/ właściwy dla gejów; dotyczący gejów; przeznaczony dla gejów - por. elektroniczny Słownik języka polskiego: http://www.sjp.pl/gejowski; Wolny wielojęzyczny wikisłownik: http://pl.wiktionary.org/wiki/gejowski [22.10.2011] i in.

${ }_{10} \mathrm{~S}$ - rzeczownik, PRP - przyimek, $\cap$ - konkatenacja: stały, obowiązkowy szyk składników związanych podrzędnie. 
9195 / туризъм за гейове 69, гейклуб 19140 / клуб за гейове 10 400, гейлитература 899 / литература за гейове 393, гейстил 197 / стил на гейове 0, гейобщност 4719 / общност на гейове 8, гейпортал 5166 / портал за гейове 0, гейдвойка 86837 / двойка гейове 1240.

O ile zatem w przypadku compositów z pierwszym komponentem homo/ хомо- dostrzegalne są pewne wspólne dla obu języków tendencje, które mimo wszystko wskazują raczej na preferowanie rodzimych środków językowych, o tyle w odniesieniu do złożeń z komponentem gej- / гeŭ - tendencje już zbieżne nie są. Język polski wyraźnie broni się przed derywatami o obcej strukturze. W języku bułgarskim natomiast konstrukcje te charakteryzuje bardzo duża częstość występowania, co może pośrednio wskazywać także na dużą produktywność serii.

Oprócz wymienionych powyżej derywatów z pierwszym członem gejw materiale polskim odnotowałam dwa interesujące, nowe złożenia. A mianowicie chodzi o neologizmy: gejoślub oraz gejodiskopolo. Oto przykłady ich użycia w tekście:

Zamiast tego różni cwaniacy polityczni wolą prowokować awantury wiedząc, że pomysły na ge jo ślu by zadziałają na „moherów” jak płachta na byka (www. forum.polityka.org.pl: Sytuacja w państwie, 19.01.2010);

Oto polskie gejodiskopolo. Śpiewane są jakieś niemieckie szlagiery, nieważne co, byle był łach. Ten występ ma epatować publiczność obciachem, robieniem z siebie i ze wszystkich innych totalnego łacha. Żaklin-Abażur nie ma głosu i tańczy jak słoń, wirując w kółko na małej scenie, ale liczą się jej pyskówki do publiczności. (www.polskaliberalna.net: $Z$ wizyta w gejklubie u PanoPani Żyrandol, 19.01.2010).

Zważywszy na strukturę wskazanych compositów, należy je uznać, w odróżnieniu od złożeń bezspójkowych z komponentem gej-, za typowe dla języka polskiego. Są to formacje egzocentryczne, w których pierwsza podstawa odprzymiotnikowa łączy się za pomocą interfiksu -o- z podstawą rzeczownikową (analogiczne do formacji typu: gołowąs, dobrobyt, lekkoduch). Warto jednak również zauważyć, że model tego typu formacji w języku polskim jest zasadniczo nieproduktywny.

Występujące zarówno w polszczyźnie, jak i w języku bułgarskim złożenia z komponentem hoто - / хомо- oraz gej- / гей- tworzą kilka wyrazi- 
stych kręgów tematycznych, które dotyczą: relacji międzyludzkich, erotyki, rozrywki (lifestyle). Wskazane obszary tematyczne niekiedy jednak trudno rozdzielić. Niemniej jednak oscylujące w obrębie wymienionych grup znaczeniowych złożenia wydają się mieć charakter stabilny, co pociąga za sobą również względną jednoznaczność. Oto przykłady formacji w podziale na grupy tematyczne:

1) relacje międzyludzkie: pol. homomatżeństwo, homopartner, homopartnerstwo, homorodzicielstwo, homorodzina, homospoleczeństwo, homouktad, homozwiqzek, hoтоаdopсja; bułg. хомобрак, хомовръзка, хомодвойка, хомообщност, хомопартньор, хомосемейство, хомоприятел; pol. gejspołeczność, gejpartner; bułg. гейвръзка, гейдвойка, гейдомакинство, геймалиинство, гейобщност, гейсдружение, гейродители;

2) erotyka:pol.homoerotyka, homofantazje, homorozpusta, homorozwiazłość; bułg. хомостраст, хомовлечение, хомоеротизъм, хомонаклонност, хомооргия, хомосекс;

3) rozrywka (lifestyle): pol. homodyskoteka, homoimpreza, homokino, homomoda, hoтороwieść; bułg. хомоотдих, хомолитература, хомоновела, хоморазвлечения, хомотуризъм; pol. gejbar, gejdyskoteka, gejikona, gejklub, gejstyl, gejturystyka; bułg. гейпортал, гейбар, гейдизайн, гейзаведение, гейкоктейл, гейкупон, гейсайт, гейсписание.

Omawiane formacje oceniane są często jako „bezkontekstowo przezroczyste" (Waszakowa 2005: 232). Jednak twierdzenie to w rzeczywistości okazuje się nie do końca słuszne. Wskazanie ogólnego obszaru odniesień semantycznych rzeczywiście nie jest trudne. Komponenty rozumiane są jako: „1. хомо- - първа съставна част на сложни думи със значение 'който се отнася до лице с хомосексуална ориентация, хомосексулист'; 2. гей- първа съставна част на сложни думи със значение 'който се отнася до гей”" (Бонджолова 2003: 48) [1. homo- - pierwsza cząstka składowa wyrazów złożonych wnosząca znaczenie: odnoszący się do osoby o orientacji homoseksualnej, do homoseksualisty; 2. gej- - pierwsza cząstka składowa wyrazów złożonych wnosząca znaczenie: odnoszący się do geja]. Kierując się dokonaną na materiale zarówno polskim, jak i bułgarskim kontekstową analizą znaczenia ${ }^{11}$, proponuję definicje te rozszerzyć w sposób następujący: homo- / gej- - pierwszy człon złożenia wnoszący znaczenie 'odnoszą-

11 Aktualizacji znaczenia poszczególnych wyrazów dokonuję, opierając się na ich użyciach w konkretnych tekstach. 
cy się do homoseksualisty / geja’: 1) właściwy dla homoseksualisty / geja (pol. homopoglad; bułg. гейповедение), 2) przeznaczony dla homoseksualisty / geja (pol. gejklub; bułg. хомотуризъм); 3) w którym homoseksualista / gej uczestniczy (pol. gejparada; bułg. хомодемонстрация) 4) skierowany przeciwko homoseksualiście / gejowi (pol. homodyskryminacja; bułg. хомофобия); 5) którego przyczyną jest homoseksualista / gej (pol. homorewolucja; bułg. гейатака). W tym miejscu należy jednak podkreślić, że zdecydowana większość omawianych formacji nie ma w żadnym z języków ustabilizowanego znaczenia. W hото- / хомо- i gej- / гей- neologizmy, tudzież okazjonalizmy, często o charakterze efemerycznym, obfituje zwłaszcza język mediów. Odczytanie właściwego znaczenia derywatów możliwe jest wyłącznie przy uwzględnieniu ich użycia w konkretnym tekście.

Powszechną praktyką, tak w mediach polskich, jak i bułgarskich, jest sięganie po skonstruowane na podstawie nowego modelu wyrazy złożone. Zwraca uwagę zwłaszcza fakt ich nagminnego stosowania w nagłówkach czy to artykułów prasowych, czy też artykułów zamieszczanych na portalach internetowych. Odnotowane formacje miewają niekiedy dość bezpardonowy charakter. Oto wybrane przykłady nagłówków:

Ho mo ro dzice są wśród nas („Gazeta Wyborcza”, 23.01.2007)

Homorodzina weteroświecie (www.onet.pl, 05.02.2009)

HomoEuropa (,Wprost” 05.07.2007)

Homoskandal w bastionie PiSu na wschodzie Polski (www.gazeta.pl, 11.05.2011)

Kolejna h o m o p row o k a cj a wKrakowie (www.fidelitas.pl, 05.01.2005)

Z wizytą w gejklubie u PanoPani Żyrandol (www.polskaliberalna.net, 19.01.2010)

Хом од ра ма в основата на убийството от «Гео Милев» (www.news. ibox.bg, 09.03.2010)

Хом о сканд д л разтресе и 40-ия парламент („Монитор”, 29.12.2005)

Гей бира се появи в Мексико (www.dariknews.bg, 20.02.2011)

Ге йразкол заради Азис и Бойко (www.novinar.bg, 24.11.2007)

Гей че н ге влезе в затвора заради наркотици (www.dir.bg, 21.07.2006)

Гласят ге й-комп рома т срещу министьр в кабинета „Борисов”?! (www.bgsniper.com, 17.03.2008) 
Na koniec wskażmy te właściwości omawianych compositów, które w największym stopniu decydują o ich atrakcyjności - zwłaszcza w języku mediów. Otóż bez wątpienia do tych cech należy przejrzystość formalna przy jednoczesnej szerokiej pojemności semantycznej. Nie zapominajmy bowiem, że ta właśnie pojemność semantyczna pozwala manipulować odbiorcą komunikatu. Nie bez znaczenia jest także łatwość tworzenia podobnych struktur, wynikająca z produktywności modelu, jego seryjnego charakteru, nieograniczonej łączliwości pierwszego członu z podstawami zwłaszcza rzeczownikowymi oraz przezroczystość komunikacyjna, wynikająca ze skrótowości i funkcjonalności złożeń (cała gama możliwości wykorzystania w tekście).

\section{Indeks wyrazów poddanych analizie}

$\begin{array}{lll}\begin{array}{l}\text { homoadopcja } \\ \text { homobiografia }\end{array} & \text { homoholokaust } & \text { homomoda } \\ \text { homobohater } & \text { homoigrzyska } & \text { homo-nazizm } \\ \text { homodwójka } & \text { homoinaczej } & \text { homoogłoszenia } \\ \text { homodyskoteka } & \text { homoinwazja } & \text { homoorientacja } \\ \text { homodyskryminacja } & \text { homokino } & \text { homopara } \\ \text { homodziecko } & \text { homokoalicja } & \text { homoparada } \\ \text { homoentuzjasta } & \text { homokryzja } & \text { homopartia } \\ \text { homoentuzjazm } & \text { homoksiądz } & \text { homo-partner } \\ \text { homoerota } & \text { homolegalizacja } & \text { homopartnerstwo } \\ \text { homoerotyczny } & \text { homolewica } & \text { homopisarz } \\ \text { homoerotyka } & \text { homoliteratura } & \text { homopogląd } \\ \text { homoerotyzm } & \text { homo-lobbysta } & \text { homopolityk } \\ \text { HomoEuropa } & \text { homomafia } & \text { homopolityka } \\ \text { homofantazje } & \text { homomałżeństwo } & \text { homopowieść } \\ \text { homofil } & \text { homomama } & \text { homoprawo } \\ \text { homofilia } & \text { homomanifa } & \text { homopropaganda } \\ \text { homofilka } & \text { homo-męczennik } & \text { homoprowokacja } \\ \text { homofon } & \text { homomiędzynarodówka } & \text { homoraj } \\ \text { homo-gwałt } & \text { homomiłość } & \text { homorewolucja }\end{array}$




\begin{tabular}{|c|c|c|}
\hline homorodzice & homoskandal & homo-tolerancja \\
\hline homorodzicielstwo & homoskłonności & homotransparent \\
\hline homorodzina & homosocjalista & homo-tropiciel \\
\hline homorozpusta & homo-sojusz & homoukład \\
\hline homorozwiązłość & homospołeczeństwo & homowolność \\
\hline homorynek & homoszaleństwo & homozachcianka \\
\hline homosceptycyzm & homo-środowisko & homozboczek \\
\hline homosceptyk & homotata & homozboczenie \\
\hline homoseksualistyczny & homoterror & homozwiązek \\
\hline homosiogium & homoterroryzm & \\
\hline
\end{tabular}

gejbar

gejdyskoteka

gejikona

gejklub

gej-literatura

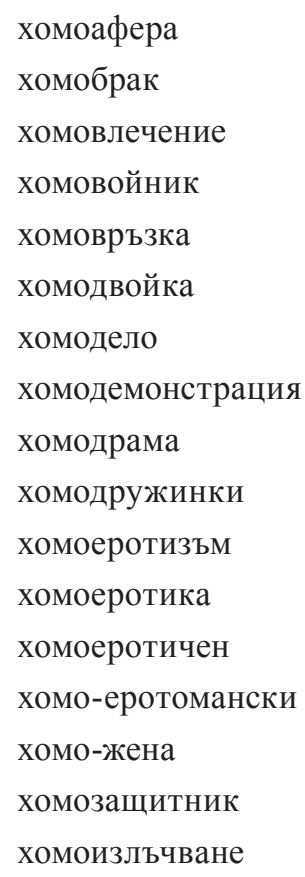

gejodiskopolo

gejośluby

gejpara

gejparada

gejpartner

хомоизпълнение
хомоизцепка
хомокласация
хомоколега
хомолитература
хомолюбов
хомомитинг
хомомомент
хомо-мъж
хомонаклонност
хомоновела
хомообщност
хомо-опит
хомооргия
хомоориентация
хомоотдих
хомопарад

gejportal

gejspołeczność

gejstyl

gejturystyka 


\begin{tabular}{|c|c|c|}
\hline хомотуризъм & хомофоб & хомо-хора \\
\hline хомоуклон & хомофобия & хомочовеци \\
\hline хомоферма & хомофобски & хомо-шегичка \\
\hline \multicolumn{3}{|l|}{ хомо-фетишизъм } \\
\hline гей бира & гейдомакинство & гей-компромат \\
\hline гей клуб & гейдрама & гейкомуна \\
\hline гей сексскандал & гейдружинка & гейкрал \\
\hline гей чат & гейелемент & гейкралица \\
\hline гей-автомобил & гейелит & гейкултура \\
\hline гей-автор & гей-ентусиазъм & гейкупон \\
\hline гейактивизъм & гейепизод & гейлагер \\
\hline гейактивист & гейескорд & гей-линия \\
\hline гейамериканец & гейетика & гейлитература \\
\hline гейасоциация & гейжелание & гейлоби \\
\hline гейафера & гейживот & гейлюбов \\
\hline гейбар & гейзаведение & геймалцинство \\
\hline гейбратство & гейзадявка & гейманифест \\
\hline гейбългарин & гейзараза & гей-марка \\
\hline гейветеран & гей-игра & геймафия \\
\hline гейвечеринка & гейидентичност & гей-министър \\
\hline гейвзаимоотношение & гейизмамник & геймитинг \\
\hline гейвокалист & гейизточник & геймъж \\
\hline гейвръзка & гейикона & гейнагласа \\
\hline гейгерой & гейинтрига & гейнаклонност \\
\hline гейгордост & гейистория & гейнападка \\
\hline гейгрупа & гейканал & гейнаркоман \\
\hline гейдвижение & гейкаубой & гейнекрофил \\
\hline гейдвойка & гейкауза & гейновини \\
\hline гейдизайн & гейквартал & гейнормалност \\
\hline гейдизайнер & гейклиентела & гейобщество \\
\hline гей-директор & гейклип & гейобщност \\
\hline гейдискотека & гейкоктейл & гейокраска \\
\hline гейдискриминация & гейкомедиантка & гейориентация \\
\hline гейдистанция & гейкомедия & гейосвобождение \\
\hline
\end{tabular}




\begin{tabular}{|c|c|c|}
\hline гейотбор & гейродител & гейтелевизия \\
\hline гейпарти & гейсайт & гейтема \\
\hline гейпартньор & гейсборище & гейтематика \\
\hline гейпартньорство & гейсватба & гейтинейджър \\
\hline гейпедофилия & гейсвита & гейтип \\
\hline гейпесничка & гейсдружение & гейтройка \\
\hline гейписател & гейсемейство & гейтуризъм \\
\hline гейпоезия & гейсериал & гейтурист \\
\hline гейполитик & гейсимвол & гейтурнир \\
\hline гейпорнография & гейскандал & гейубиец \\
\hline гейпортал & гейснимка & гейуебсайт \\
\hline гейправа & гейсобственик & гейуклон \\
\hline гейпразник & гейсонет & гейфестивал \\
\hline гейпрайд & гейсписание & гейфилм \\
\hline гейпрегръдка & гейспортист & гейфондация \\
\hline гейпрезидент & гейсправочник & гейхотел \\
\hline гейпремиер & гейсреда & гейхудожник \\
\hline гейприключение & гейстолица & гейцентър \\
\hline гейпродукт & гейсцена & гейченге \\
\hline гейпроституция & гейсъбота & гейчувствителност \\
\hline гейразказ & гейсъюз & гейшампион \\
\hline гейразкол & гейсюжет & гейшествие \\
\hline гейреклама & гейтаймс & \\
\hline
\end{tabular}

\section{Bibliografia}

Burkacka I., 2010, Klasyfikacja słowotwórcza nowszych zapożyczeń, Linguistica Copernicana (2)4, s. 229-239.

Crystal D., 1999, The Cambridge Encyklopedia of Language. English as a Global Language, Cambridge: CUP.

DŁugosz N., 2010, Composita wewnątrzwspólnotowe - wyrazy złożone z cząstką евро- w języku bułgarskim, Slavia Meridionalis. Studia Slavica et Balcanica, t. 10: Paradygmaty badawcze jezzykoznawstwa poludniowostowiańskiego, s. $69-86$. 
Dıugosz N., 2011, Bułgarskie rzeczowniki złożone z komponentem чалга-, Studia Slavica - Slovanské studie, z. XV, Ostrava-Opole: Universitas Ostraviensis Uniwersytet Opolski, s. 345-352.

JADACKa H., 2001, System stowotwórczy polszczyzny (1945-2000), Warszawa: Wydawnictwo Naukowe PWN.

KaProń-CharzyńSKa I., 2005, Derywacja ujemna we wspótczesnym języku polskim. Rzeczowniki i przymiotniki, Toruń: TOP KURIER.

Nagórko A., 1997, Miejsce słowotwórstwa w teorii języka, Biuletyn PTJ LIII, s. 49-61.

Ochmann D., 2004, Nowe wyrazy złożone o podstawie zdezintegrowanej w języku polskim, Kraków: Księgarnia Akademicka.

OHNHeISER I. (red.), 2003, Komparacja systemów i funkcjonowania wspótczesnych języków stowiańskich. 1. Stowotwórstwo / Nominacja, Opole: Wydawnictwo Uniwersytetu Opolskiego.

Szczyszek M., 2010, Przejawy internacjonalizacji we współczesnej polszczyźnie na przykładzie zjawisk słowotwórczych, Linguistica Copernicana (2)4, s. 215-227.

Waszakowa K., 2005, Przejawy internacjonalizacji w stowotwórstwie wspótczesnej polszczyzny, Warszawa: Wydawnictwo Uniwersytetu Warszawskiego.

Аврамова Цв., 2003, Словообразувателни тенденции при съществителните имена в българския и чешкия език в края на ХХ век, София: Херон Прес.

Аврамова Цв., 2008, Тенденции в българското словообразуване на границата между два века, w: Z. Rudnik-Karwatowa (red.), Współczesna komunikacja językowa. Najnowsze zmiany w leksyce i stowotwórstwie języków stowiańskich, Warszawa: Slawistyczny Ośrodek Wydawniczy.

Благоева Д., 2007, Неологизмите в българския език, LiterNet 2(87) - http://liternet.bg/publish13/d_blagoeva/neologizmite.htm, [22.10.2011].

Бонджолова В., 2003, Неологичен речник, Велико Търново: Gaberoff.

Бонджолова В., 2009, (Не)съществуващи думи: оказионализмите в медийния текст, Велико Търново: Университетско издателство „Св. св. Кирил и Методий".

ЗидАРова В., 2009, Преглед на титрологичните практики в новата българска npeca, http://www.belb.net/personal/zidarova/headlines_press.htm, [24.08.2011].

РАДЕВа В., АвРАМОВа Ц., БАЛтова Ю. (ред.), 2009, СловообразУване илексикология. Доклади от Десета международна конференция на Комисията по славянско словообразуване при Международния комитет на славистите, София, 1-6 октомври 2007 г., София: Университетско издателство „Св Климент Охридски".

РНДБЕ: КАСАБОв И. (гЛ. ред.), 2006, Речник на новите думи в българския език, т. 3 (второ допълнено и преработено издание), София: БАН. 


\section{Polish and Bulgarian compound nouns with components homo- / xomo- and gej- / гей- as a sign of internationalization in the media language \\ ( su m mary)}

The present article is focused on the newest compounds with the foreign element homo- / хомо- and gej- / гей- in Polish and Bulgarian languages. The source of language material are mainly Polish and Bulgarian press texts. The morphological structure of the compound types under discussion is described. Difficulties regarding the classification of new structures are stressed. Semantic analysis is introduced in the form of a proposal for definitions of the first components of the compound. In order to document the contexts of use of the lexemes (indirectly, the frequency of derivates and productivity of series), an Internet search query is performed. Essential differences between productivity and functioning of both types of compounds in the languages under discussion are described. Formal and semantic properties of the compounds, which may have a significant impact on the significant presence of such formations in the media language, are specified. 